\title{
Key Factors for Online Branding Success in India: An ISM Approach
}

\author{
Mandeep Kaur \\ Sri Guru Tegh Bahadur Institute of Management \& IT, Affiliated to GGSIPU, Delhi, India \\ E-mail: mandeepkour01@gmail.com
}

\begin{abstract}
In today's digital age it is essential to analyse the factors that influence the success of online branding. Pure play e-tailer, Brick and mortar, click and mortar companies are required to follow online branding strategy. As online branding is the need of the hour companies are moving on the track where the ultimate destination is to adopt online branding as the strategy to stay ahead. Online branding is moving at the pace of the light. To keep up, companies need a robust foundation with the judgment to think precariously about the critical success factors for online branding. The purpose of the paper is to identify factors that influence the success of online branding, interrelationship among those factors and categories them in line with its driving and dependence power. These factors will help to prepare the model for companies who are planning to go for online branding strategy. Interpretative Structural Modelling approach is used to construct this model. The result found that both online factors and offline factors influence the success of online branding. Future research may endeavour to statistically validate the proposed model and may also expand the model by suggesting other factors that are influencing the success of online branding. Little research has investigated the interrelationship among factors which are affecting the success of online branding and thereby inducing companies to go for online branding. In addition the present paper contributed insights developed from the model that would help companies in taking decision related to online branding.
\end{abstract}

Keywords: Online Branding, Interpretative structural modeling, Critical Success factors.

\section{INTRODUCTION}

Brands which are means to identify a company and its products are taking a new form in the technology driven marketing environment. Brand means a name, symbol, design or combination of them that are used by company or a group of companies to differentiate itself from its competitors (American Marketing Association, 1960). In the present digital age the term brand is not just brand but it represents online brands. Online branding or e-branding means the design and development of communication strategies precisely for brands to have sense and background on the web (Kotler et al, 2010). Online branding means Branding done through electronic means. Online branding means creating brand with the help of internet, making a website recognised, making brands with an end of the term dot com and above all creating brand awareness, brand identity, brand integrity (Levine, 2003). Branding for brick and mortar stores which is done with the intention to create domestic market has been reshaped as branding with the intention to have an international reach. Branding done by brick and mortar stores induced customers to impulse buying but online branding reinforces brand recognition (Dubberly, 2000). Online Branding has various Critical Success Factors such as Word of Mouth, Advertisements, Loyalty, Brand Equity, Satisfaction, Trust, Emotional connection, Design and technology, Brand name (Eid et al, 2012). To successfully establish online brands companies are using a number a number of strategies - take first mover advantage in establishing online brand (Doyle, 1990). Moreover follow a series of steps to comprehend, appeal, appoint, keep and learn about the target market (Kierzkowski et al., 1996). Customer participation in brand development through viral marketing, and building social communities are showing the role that internet can play in Online branding (De Chernatony, 2010).

\section{IDENTIFICATION OF VARIABLES AFFECTING THE RETAIL SECTOR}

In the presence digital age where India is actively contributing to the world economy companies are also contributing for the same by establishing online presence. Online presence break the barriers of distance but also build trust among consumers. Online branding is important not only for the consumers but also for the companies as online branding helps in making a name for the company and being able to make consumers to come to company instead of company going to consumers. Secondly, it helps to cut down on advertising expenses and the company can have a 24 hour store front of its business. To identify the variables that are inducing the success of online branding, and then to build mutual relationship among variables, brainstorming sessions were conducted with experts selected from both specialisations - Brand management and E-commerce. Initially, meeting was organised with the Manager who have online presence of business. In this meeting, 3 experts with brand management specialisation and 3 from the ecommerce market were selected. The selected experts had around seven years of experience in the online business. Literature associated with factors inducing success of online branding was distributed among the experts. Within twenty one days, a brainstorming session was conducted to determine the variables. Initially, twenty two variables were identified. Thereafter through discussion the number of variables was reduced to eleven as some of the variables were of same characteristics. After identifying the variables 
a session was conducted to build the relationship among the variables. Finally, after a brainstorming session following variables was identified:

\section{A. Trust}

In an online environment customers rely more on the information provided on the company's website. To build trust, website design is playing a crucial role (Hoffman et al., 1999). Trust is associated with security in the mind of consumer and it is key factor which induces online purchasing decision of consumer (Gommans et al., 2001). People depend more on their dispositions to trust when they face unusual situation (Rotter, 1971). While online shopping consumers cannot check the quality of the product. Moreover consumer cannot ensure the security of personal as well as financial information (Lee and Turban, 2001). Therefore trust has an important power in establishing online brands.

\section{B. Loyalty}

Retaining customers and nurturing customer loyalty are important for creating powerful online brands and helps companies in establishing a competitive edge over other in the electronic market place. Brand loyalty in the virtual reality is progression from conventional product determined to distribution determined concept. Moreover there is shift from marketer controlled to consumer controlled concept (Reichheld et al., 2000). Brand or online loyalty is related to customer support services, on-time delivery of the product or service, reasonably priced shipping, trustworthy privacy policies (Schefter et al., 2000). Brand loyalty is a hierarchy of effect model with cognitive, affective, conative and action dimension (Oliver, 1997).

\section{Brand Name}

For internet companies' brand name magnify with the domain name and the domain name acts as a mean of access to the website (Clauser, 2001). The probability of purchase increases when a well-respected brand is offered as compared to less well respected brand as brand awareness reduces the perceived risk in the mind of consumers (Erdem et al., 1998). Consumers can remember product information for familiar brand and have important advantage in marketplace (Kent et al.,, 1994).

\section{Satisfaction}

Customer satisfaction resides a vital position in marketing practice. One of the studies conducted on customer satisfaction presented a model of customer satisfaction in which the antecedents are expectations, disconfirmation and consequences are intention to purchase (Oliver, 1980). Disconfirmation is an intervening variable which effect satisfaction and the impact of disconfirmation is taken by expectation and perceived performance. They conducted an experiment on both durable and non-durable goods. The result found that the effects are not same for both durable and non-durable goods. Satisfaction depends on the performance of the durable good (Churchill et al., 1982).

\section{E. Brand Equity}

Brand equity comprises five dimensions that contribute to brand equity. These dimensions are brand loyalty, brand awareness, brand association, perceived level of quality and unidentified proprietary brand assets (Aaker, 1991). The marketing efforts' effect that accrue to an item for consumption with its brand name as related to those if the same item for consumption did n't have a brand name (Ailawadi et al., 2003). Brand equity can be well-defined from the consumer perspective as a loyalty, value or competitive image not explained by product features and from the company's perspective it is an incremental cash flows resulting from the product with brand name as compared to those which are without brand name. As Leuthesser (1988) define brand equity from the consumer perspective as a utility, loyalty, or differentiated clear image not explained by product attributes and from the firm perspective as the cash flows resulting from the product with the brand name compared with that which would result without the brand name.

\section{F. Word of Mouth}

Word of mouth is a tool which companies can use to realise competitive advantage. Word of mouth is an indicator of customer loyalty. (Mazzarol et al., 2007). Customers who are loyal will generate positive word of mouth for the company (Hagel and Armstrong, 1997). Online word of mouth is an online stage to exchange positive or negative feelings among existing as well as future customers. Furthermore word of mouth is an influential factor for exchanging information among customers (Duan et al, 2008). Word of mouth has a significant impact on brand trust. It spreads quickly on the web as compared to offline mode. Negative word of mouth leads to complaints and it spoils brand trust of each customer (Harrison- Walker, 2001). Online WOM is more powerful than the traditional WOM as it has unique characteristics such as convenience, speed, one-to-many and many-to-many interaction. It may not include face- to-face interaction (Phelps et al., 2004).

\section{G. Emotional Connection}

Emotional Connection begins with the brand belief which is a concept not related to just brand challengers, nor niche brand, nor one -off brand. Furthermore it is described that companies can have emotional connection with consumer to achieve better brand health but companies are wrong if they believe that emotional connection can be achieved through other ways like brand personality, communication (Edwards e al., 2007). On the internet building emotional connection with consumer is valued, but in online companies there is less opportunity to create a connection; fortunately building 
emotional connection can be effective for online companies (Clauser, 2001).

\section{H. Website Design}

A company's site is a promotional affair in its own right. So the website assists as a correspondent of a business's value offer and brand ability (Simmons, 2007). In a study the determinants of successful website design was investigated. The determinants found were Website page loading speed, Company's related content on the website, Ease of Navigation, Security, Marketing/Consumer focus (Gehrke et al., 1999). The two factor model was developed in a study to find some facets of the Herzberg's theory in context of a study on website. The purpose was to use Herzberg's theory as a logical tool to distinguish website related factors whose existence is taken for granted by users of the website from those that provide satisfaction and pleasure to the website users. (Zhang et al., 2000).

\section{Viral Marketing}

Viral marketing is a more powerful tool than third party advertising as it carries an oblique endorsement from a friend. The spillover effect of viral marketing is powerful. It can also be defined as network enriched word of mouth (Jurvetson, 2000). Word of mouth can influence the consumers' purchasing decision but it's difficult for advertisement company to tap into but in viral marketing it can be tapped as the product is advertised as part of the communication (Leskovec, 2007).

\section{J. Social Communities}

Social communities are the specialised, non-geographical area bounded virtual communities formed on the basis of social relationship among followers of a brand (Muniz and O’ Guinn, 2001). Social communities help companies in the sense that it let the customers assign meanings to the brand (Rubinstein \& Griffiths, 2001). A survey had concluded that $90 \%$ of the people trust recommendations given by people they are familiar with while $70 \%$ trust recommendations that are posted online (The Nielsen Company, 2009).

\section{K. Advertisement}

The factors that contribute to the individual's perception of both online and offline advertisements are entertainment, irritation, credibility, informativesness and demography. Moreover interactivity is major factor contributing to consumer's perception. (Wang et al., 2002). Banner advertisements have positive impact on advertisement recall, unaided recall; brand recognition and brand awareness (Dreze et al., 2003). Another study investigated how advertising frequency impact the advertising effectives in terms of two different aspects. One is direct response and the one is Brand awareness where direct response can be calculated by the number of customers who click on the advertisement and reach the website. Brand awareness and Brand awareness can be measured through a survey of a few of the visitors to the site (Broussard, 2000).

\section{III.METHODOLOGY}

While dealing with complex issues people usually confront difficulties. In a system, there are a number of variables which are directly or indirectly related and relationship among these variables increases the complexity of that system. It is hard to confront with such a complex system where the structure of those variables in the system is not clear and the relationships among variables is not clearly identified. Interpretive Structural modelling (ISM) is therefore one such method which helps in ascertaining a structure within a complex system. There are many variables which are inducing the success of online branding. To clearly know the system 'Online Branding' and to recognise the interrelationship among the variables that are driving the success of Online Branding ISM contributes a vital role.

It helps in finding the interrelationship among variables and also helps in separating these variables in accordance to their driving and dependence power. ISM is technique in which involves a series of steps are used to originate a well orderly model. In this technique, a large number of directly and indirectly linked variables are arranged into a comprehensive model. Subsequently, the model is developed that portrays the structure of a complex issue with a systematically organised pattern representing graphics as well as words.

ISM starts with identification of variables that are related to a given problem. After identification of variables relationship among these variables is recognized with the help of group problem solving technique. When relationship among variables are identified pair-wise comparison is done. After pair wise comparison a matrix is created. The matrix thus formed is denoted to as Structural SelfInteraction Matrix (SSIM). Later on, the SSIM is transformed into reachability matrix where the relationships are converted into zeros and ones.

After preparing Reachability matrix, transitive relations are found through transitivity concept. Then a final reach ability matrix is made where transitive relations go into the reach ability matrix. Then, the classification of the variables and a structural, well-arranged model called ISM is derived (Agarwal et al., 2007). In the present research, ISM is used to achieve the following objectives:

1. To identify the variables that are inducing the success of online branding.

2. To extract interrelationship among the variables that are inducing the success of online branding.

3. To categorise the variables in accordance to their dependence and driving power. 


\section{A. Structural Self-Interaction Matrix (SSIM)}

In the present paper, for identifying the contextual relationship among variables opinions of the 5 experts with brand management specialization and 5 from the ecommerce market were selected. Based on the relationship among the variables SSIM has been made. Four symbols are used to portray the relationship between the variables ( $\mathrm{i}$ and j) are as follows:

V-it represents that variable i will help to achieve variable j; A-it represents that variable $\mathrm{j}$ will help to achieve $\mathrm{i}$;

$\mathrm{X}$-it represents that variable $\mathrm{i}$ and $\mathrm{j}$ will help to achieve each other; and

$\mathrm{O}$-it represents that variable $\mathrm{i}$ and $\mathrm{j}$ are unrelated.

TABLE I STRUCTURAL SELF-INTERACTION MATRIX (SSIM)

\begin{tabular}{|c|c|c|c|c|c|c|c|c|c|c|}
\hline Elements & $\mathbf{1 1}$ & $\mathbf{1 0}$ & $\mathbf{9}$ & $\mathbf{8}$ & $\mathbf{7}$ & $\mathbf{6}$ & $\mathbf{5}$ & $\mathbf{4}$ & $\mathbf{3}$ & $\mathbf{2}$ \\
\hline 1 & O & X & A & A & A & A & A & V & A & V \\
\hline 2 & V & A & A & A & A & O & A & A & A & \\
\hline 3 & O & O & V & O & V & O & O & O & & \\
\hline 4 & O & A & A & A & A & O & A & & & \\
\hline 5 & O & V & O & O & A & O & & & & \\
\hline 6 & V & O & O & O & O & & & & & \\
\hline 7 & V & O & O & O & & & & & & \\
\hline 8 & O & O & A & & & & & & & \\
\hline 9 & O & V & & & & & & & & \\
\hline 10 & V & & & & & & & & & \\
\hline
\end{tabular}

In Table 1 Structural self-interaction matrix (SSIM) is made and the use of symbols $\mathrm{V}, \mathrm{A}, \mathrm{X}$ and $\mathrm{O}$ is explained.

Variable 1 leads to variable 2 so the symbol ' $\mathrm{V}$ ' is written in the cell $(1,2)$; variable 1 leads to variable 3 so symbol ' $A$ ' is written in the cell $(1,3)$; Variable 1 and 10 lead to each other so symbol ' $\mathrm{X}$ ' is written in the cell $(1,10)$; Variable 1 and 11 do not lead to each other so symbol ' $O$ ' has been given in the cell $(1,11)$ and so on.

\section{B. Reachability Matrix}

Structural self-interaction matrix was formed in the previous step. In the next step Binary matrix also known as initial reachability matrix is formed by transforming SSIM into initial reachability matrix. For this symbols V, A.X, O has been substituted with 0 and 1 . Following are the rules used for this purpose:

1. If the (i,j) entry in the SSIM is $V$, then the (i,j) entry in the reachability matrix becomes 1 and the $(\mathrm{j}, \mathrm{i})$ entry becomes 0 .

2. If the (i,j) entry in the SSIM is $A$, then the (i,j) entry in the matrix becomes 0 and the $(\mathrm{j}, \mathrm{i})$ entry become 1 .

3. If the the (i,j) entry in the SSIM is $X$, them the (i,j) entry in the matrix becomes 1 and the $(\mathrm{j}, \mathrm{i})$ entry also becomes 1 .
4. If the (i,j) entry in the SSIM is $\mathrm{O}$, then the (i,j) entry in the matrix becomes 0 and the $(\mathrm{j}, \mathrm{i})$ entry also becomes 0 .

By applying the above rules, a binary matrix or initial reachability matrix is prepared as shown in Table 2.

\section{Partitioning the Reach ability Matrix}

For partitioning the reach ability matrix firstly, both the reach ability set and antecedent set for each variable is formed from the final reach ability matrix. Thereafter, the interaction set of these sets is calculated for all the variables.

The variable for which both reachability and intersection set is same, assigned first level and these iterations is continued till the level for each variable is found. This process is completed in six iterations as given in Tables number 4 to 12. The result of these iterations is presented in the Table 11.

TABLE II INITIAL REACHABILITY MATRIX

\begin{tabular}{|c|c|c|c|c|c|c|c|c|c|c|c|}
\hline Elements & $\mathbf{1}$ & $\mathbf{2}$ & $\mathbf{3}$ & $\mathbf{4}$ & $\mathbf{5}$ & $\mathbf{6}$ & $\mathbf{7}$ & $\mathbf{8}$ & $\mathbf{9}$ & $\mathbf{1 0}$ & $\mathbf{1 1}$ \\
\hline 1 & 1 & 1 & 0 & 1 & 0 & 0 & 0 & 0 & 0 & 1 & 0 \\
\hline 2 & 0 & 1 & 0 & 0 & 0 & 0 & 0 & 0 & 0 & 0 & 1 \\
\hline 3 & 1 & 1 & 1 & 0 & 0 & 0 & 1 & 0 & 1 & 0 & 0 \\
\hline 4 & 0 & 1 & 0 & 1 & 0 & 0 & 0 & 0 & 0 & 0 & 0 \\
\hline 5 & 1 & 1 & 0 & 1 & 1 & 0 & 0 & 0 & 0 & 1 & 0 \\
\hline 6 & 1 & 0 & 0 & 0 & 0 & 1 & 0 & 0 & 0 & 0 & 1 \\
\hline 7 & 1 & 1 & 0 & 1 & 1 & 0 & 1 & 0 & 0 & 0 & 1 \\
\hline 8 & 1 & 1 & 0 & 1 & 0 & 0 & 0 & 1 & 0 & 0 & 0 \\
\hline 9 & 1 & 1 & 0 & 1 & 0 & 0 & 0 & 1 & 1 & 1 & 0 \\
\hline 10 & 1 & 1 & 0 & 1 & 0 & 0 & 0 & 0 & 0 & 1 & 1 \\
\hline 11 & 0 & 0 & 0 & 0 & 0 & 0 & 0 & 0 & 0 & 0 & 1 \\
\hline
\end{tabular}

5. $1^{*}$ entries are made in the initial reachability matrix to incorporate transitivity. The final reachability matrix is presented as exhibited in the Table 3 :

TABLE III FINAL REACHABILITY MATRIX

\begin{tabular}{|c|c|c|c|c|c|c|c|c|c|c|c|}
\hline Elements & $\mathbf{1}$ & $\mathbf{2}$ & $\mathbf{3}$ & $\mathbf{4}$ & $\mathbf{5}$ & $\mathbf{6}$ & $\mathbf{7}$ & $\mathbf{8}$ & $\mathbf{9}$ & $\mathbf{1 0}$ & $\mathbf{1 1}$ \\
\hline 1 & 1 & 1 & 0 & 1 & 0 & 0 & 0 & 0 & 0 & 1 & $1^{*}$ \\
\hline 2 & 0 & 1 & 0 & 0 & 0 & 0 & 0 & 0 & 0 & 0 & 1 \\
\hline 3 & 1 & 1 & 1 & $1^{*}$ & $1^{*}$ & 0 & 1 & $1^{*}$ & 1 & $1^{*}$ & $1^{*}$ \\
\hline 4 & 0 & 1 & 0 & 1 & 0 & 0 & 0 & 0 & 0 & 0 & $1^{*}$ \\
\hline 5 & 1 & 1 & 0 & 1 & 1 & 0 & 0 & 0 & 0 & 1 & $1^{*}$ \\
\hline 6 & 1 & $1^{*}$ & 0 & $1^{*}$ & 0 & 1 & 0 & 0 & 0 & $1^{*}$ & 1 \\
\hline 7 & 1 & 1 & 0 & 1 & 1 & 0 & 1 & 0 & 0 & $1^{*}$ & 1 \\
\hline 8 & 1 & 1 & 0 & 1 & 0 & 0 & 0 & 1 & 0 & $1^{*}$ & $1^{*}$ \\
\hline 9 & 1 & 1 & 0 & 1 & 0 & 0 & 0 & 1 & 1 & 1 & $1^{*}$ \\
\hline 10 & 1 & 1 & 0 & 1 & 0 & 0 & 0 & 0 & 0 & 1 & 1 \\
\hline 11 & 0 & 0 & 0 & 0 & 0 & 0 & 0 & 0 & 0 & 0 & 1 \\
\hline
\end{tabular}


TABLE IV ITERATION I

\begin{tabular}{|c|c|c|c|c|}
\hline Element & $\begin{array}{c}\text { Reachability } \\
\text { Set }\end{array}$ & $\begin{array}{c}\text { Antecedent } \\
\text { Set }\end{array}$ & $\begin{array}{c}\text { Intersection } \\
\text { Set }\end{array}$ & Level \\
\hline 1 & $1,2,4,10,11$ & $\begin{array}{c}1,3, \\
5,6,7,8,9,10\end{array}$ & 1,10 & \\
\hline 2 & 2,11 & $\begin{array}{c}1,2,3,4,5,6, \\
7,8,9,10 \\
\end{array}$ & 2 & \\
\hline 3 & $\begin{array}{c}1,2,3,4,5,7 \\
8,9,10,11\end{array}$ & 3 & 3 & \\
\hline 4 & $2,4,11$ & $\begin{array}{c}1,3,4,5,6,7 \\
8,9,10\end{array}$ & 4 & \\
\hline 5 & $\begin{array}{c}1,2,4,5,10,1 \\
1\end{array}$ & $3,5,7$ & 5 & \\
\hline 6 & $\begin{array}{c}1,2,4,6,10,1 \\
1\end{array}$ & 6 & 6 & \\
\hline 7 & $1,2,4,5,7,10$ & 3,7 & 7 & \\
\hline 8 & $\begin{array}{c}1,2,4,8,10,1 \\
1\end{array}$ & $3,8,9$ & 8 & \\
\hline 9 & $\begin{array}{c}1,2,4,8,9,10 \\
, 11\end{array}$ & 3,9 & 9 & \\
\hline 10 & $1,2,4,10,11$ & $\begin{array}{c}1,3, \\
5,6,7,8,9,10\end{array}$ & 1,10 & \\
\hline 11 & 11 & $\begin{array}{l}1,2,3,4,5,6, \\
7,8,9,10,11\end{array}$ & 11 & I \\
\hline
\end{tabular}

TABLE V ITERATION II

\begin{tabular}{|c|c|c|c|c|}
\hline Element & $\begin{array}{c}\text { Reachability } \\
\text { Set }\end{array}$ & $\begin{array}{c}\text { Antecedent } \\
\text { Set }\end{array}$ & $\begin{array}{c}\text { Intersection } \\
\text { Set }\end{array}$ & Level \\
\hline 1 & $1,2,4,10$ & $\begin{array}{c}\text { 1, 3, 5,6,7 } \\
\quad 8,9,10\end{array}$ & 1,10 & \\
\hline 2 & 2 & $\begin{array}{l}1,2,3,4,5 \\
6,7,8,9,10\end{array}$ & 2 & II \\
\hline 3 & $\begin{array}{c}1,2,3,4,5 \\
7,8,9,10\end{array}$ & 3 & 3 & \\
\hline 4 & 2,4 & $\begin{array}{c}1,3,4,5,6, \\
7,8,9,10\end{array}$ & 4 & \\
\hline 5 & $\begin{array}{c}1,2,4 \\
5,10\end{array}$ & $3,5,7$ & 5 & \\
\hline 6 & $\begin{array}{c}1,2,4, \\
6,10\end{array}$ & 6 & 6 & \\
\hline 7 & $\begin{array}{l}1,2,4 \\
5,7,10\end{array}$ & 3,7 & 7 & \\
\hline 8 & $\begin{array}{c}1,2,4 \\
8,10\end{array}$ & $3,8,9$ & 8 & \\
\hline 9 & $\begin{array}{c}1,2,4,8 \\
9,10\end{array}$ & 3,9 & 9 & \\
\hline 10 & $1,2,4,10$ & $\begin{array}{c}1,3, \\
5,6,7,8,9,10\end{array}$ & 10 & \\
\hline
\end{tabular}

TABLE VI ITERATION III

\begin{tabular}{|c|c|c|c|c|}
\hline Element & $\begin{array}{c}\text { Reachability } \\
\text { Set }\end{array}$ & $\begin{array}{c}\text { Antecedent } \\
\text { Set }\end{array}$ & $\begin{array}{c}\text { Intersection } \\
\text { Set }\end{array}$ & Level \\
\hline 1 & $1,4,10$ & $\begin{array}{c}1,3,5,6, \\
7,8,9,10\end{array}$ & 1,10 & \\
\hline 3 & $\begin{array}{c}1,3,4, \\
6,7,8,9,10\end{array}$ & 3 & 3 & \\
\hline 4 & 4 & $\begin{array}{c}1,3,4,5,6, \\
7,8,9,10\end{array}$ & 4 & III \\
\hline 5 & $1,4,5,10$ & $3,5,7$ & 5 & \\
\hline 6 & $1,4,3,6,10$ & 3 & 6 & \\
\hline 7 & $1,4,5,7,10$ & 3,7 & 7 & \\
\hline 8 & $1,4,8,10$ & $3,8,9$ & 8 & \\
\hline 9 & $1,4,8,9,10$ & 3,9 & 9 & \\
\hline 10 & $1,4,10$ & $\begin{array}{c}1,3, \\
5,6,7,8,9,10\end{array}$ & 1,10 & \\
\hline
\end{tabular}

TABLE VII ITERATION IV

\begin{tabular}{|c|c|c|c|c|}
\hline Element & $\begin{array}{c}\text { Reachability } \\
\text { Set }\end{array}$ & $\begin{array}{c}\text { Antecedent } \\
\text { Set }\end{array}$ & $\begin{array}{c}\text { Intersection } \\
\text { Set }\end{array}$ & Level \\
\hline 1 & 1,10 & $\begin{array}{c}1,3, \\
5,6,7,8,9,10\end{array}$ & 1,10 & \\
\hline 3 & $\begin{array}{c}1,3, \\
5,7,8,9,10\end{array}$ & 3 & 3 & \\
\hline 5 & $1,5,10$ & $3,5,7$ & 5 & \\
\hline 6 & $1,6,10$ & 6 & 6 & \\
\hline 7 & $1,5,7,10$ & 3,7 & 7 & \\
\hline 8 & $1,8,10$ & $3,8,9$ & 8 & \\
\hline 9 & $1,8,9,10$ & 3,9 & 9 & \\
\hline 10 & 1,10 & 1,3, & 1,10 & IV \\
& & $5,6,7,8,9,10$ & & \\
\hline
\end{tabular}

TABLE VIII ITERATION V

\begin{tabular}{|c|c|c|c|c|}
\hline Element & $\begin{array}{c}\text { Reachability } \\
\text { Set }\end{array}$ & $\begin{array}{c}\text { Antecedent } \\
\text { Set }\end{array}$ & $\begin{array}{c}\text { Intersection } \\
\text { Set }\end{array}$ & Level \\
\hline 3 & $3,5,7,8,9$ & 3 & 3 & \\
\hline 5 & 5 & $3,5,7$ & 5 & $\mathrm{~V}$ \\
\hline 6 & 6 & 6 & 6 & $\mathrm{~V}$ \\
\hline 7 & 5,7 & 3,7 & 7 & \\
\hline 8 & 8 & $3,8,9$ & 8 & $\mathrm{~V}$ \\
\hline 9 & 8,9 & 3,9 & 9 & \\
\hline
\end{tabular}

TABLE IX ITERATION VI

\begin{tabular}{|c|c|c|c|c|}
\hline Element & $\begin{array}{c}\text { Reachability } \\
\text { Set }\end{array}$ & $\begin{array}{c}\text { Antecedent } \\
\text { Set }\end{array}$ & $\begin{array}{c}\text { Intersection } \\
\text { Set }\end{array}$ & Level \\
\hline 3 & $3,7,9$ & 3 & 3 & \\
\hline 7 & 7 & 3,7 & 7 & VI \\
\hline 9 & 9 & 9 & 9 & VI \\
\hline
\end{tabular}

TABLE X ITERATION VII

\begin{tabular}{|c|c|c|c|c|}
\hline Element & $\begin{array}{c}\text { Reachability } \\
\text { Set }\end{array}$ & $\begin{array}{c}\text { Antecedent } \\
\text { Set }\end{array}$ & $\begin{array}{c}\text { Intersection } \\
\text { Set }\end{array}$ & Level \\
\hline 3 & 3 & 3 & 3 & VII \\
\hline
\end{tabular}


TABLE XI LEVEL PARTITIONS

\begin{tabular}{|c|c|c|c|c|}
\hline Element & $\begin{array}{c}\text { Reachability } \\
\text { Set }\end{array}$ & $\begin{array}{c}\text { Antecedent } \\
\text { Set }\end{array}$ & $\begin{array}{c}\text { Intersection } \\
\text { Set }\end{array}$ & Level \\
\hline 1 & $1,2,4,10,11$ & $\begin{array}{c}1,3, \\
5,6,7,8,9,10\end{array}$ & 1,10 & IV \\
\hline 2 & 2,11 & $\begin{array}{c}1,2,3,4,5,6, \\
7,8,9,10\end{array}$ & 2 & II \\
\hline 3 & $\begin{array}{c}1,2,3,4,5, \\
7,10,11\end{array}$ & 3 & 3 & VII \\
\hline 4 & $2,4,11$ & $\begin{array}{c}1,3,4,5,6, \\
7,8,9,10\end{array}$ & 4 & III \\
\hline 5 & $1,2,4,5,10,11$ & $3,5,7$ & 5 & V \\
\hline 6 & $1,2,4,6,10$ & 6 & 6 & V \\
\hline 7 & $1,2,4,5,7,10$ & 3,7 & 7 & VI \\
\hline 8 & $1,2,4,8,10,11$ & 8,9 & 8 & V \\
\hline 9 & $1,2,4,8,9,10,11$ & 9 & 9 & VI \\
\hline 10 & $1,2,4,10,11$ & $\begin{array}{c}1,3,5,6, \\
7,8,9,10\end{array}$ & 1,10 & IV \\
\hline 11 & 11, & $\begin{array}{c}1,2,3,4,5, \\
8,9,10,11\end{array}$ & 11 & I \\
\hline
\end{tabular}

\section{Developing Conical Matrix}

A conical matrix is formed by grouping the variables according to the level in which it is selected from the final reachability matrix as presented in Table 12 .

TABLE XII CONICAL FORM OF REACHABILITY MATRIX

\begin{tabular}{|c|c|c|c|c|c|c|c|c|c|c|c|}
\hline Elements & $\mathbf{1 1}$ & $\mathbf{2}$ & $\mathbf{4}$ & $\mathbf{1}$ & $\mathbf{1 0}$ & $\mathbf{5}$ & $\mathbf{6}$ & $\mathbf{8}$ & $\mathbf{7}$ & $\mathbf{9}$ & $\mathbf{3}$ \\
\hline 11 & 1 & 0 & 0 & 0 & 0 & 0 & 0 & 0 & 0 & 0 & 0 \\
\hline 2 & 1 & 1 & 0 & 0 & 0 & 0 & 0 & 0 & 0 & 0 & 0 \\
\hline 4 & 1 & 1 & 1 & 0 & 0 & 0 & 0 & 0 & 0 & 0 & 0 \\
\hline 1 & 1 & 1 & 1 & 1 & 1 & 0 & 0 & 0 & 0 & 0 & 0 \\
\hline 10 & 1 & 1 & 1 & 1 & 1 & 0 & 0 & 0 & 0 & 0 & 0 \\
\hline 5 & 1 & 1 & 1 & 1 & 1 & 1 & 0 & 0 & 0 & 0 & 0 \\
\hline 6 & 1 & 1 & 1 & 1 & 1 & 0 & 1 & 0 & 0 & 0 & 0 \\
\hline 8 & 1 & 1 & 1 & 1 & 1 & 0 & 0 & 1 & 0 & 0 & 0 \\
\hline 7 & 1 & 1 & 1 & 1 & 1 & 1 & 0 & 0 & 1 & 0 & 0 \\
\hline 9 & 1 & 1 & 1 & 1 & 1 & 0 & 0 & 1 & 0 & 1 & 0 \\
\hline 3 & 1 & 1 & 1 & 1 & 1 & 1 & 0 & 1 & 1 & 1 & 1 \\
\hline
\end{tabular}

\section{DEVELOPMENT OF DIAGRAPH}

Firstly, an initial digraph which includes transitive links is formed from the conical form of reachability matrix.

After removing the indirect links, the final digraph is derived as represented in fig. 1.

From Fig. 1, it is noted that "Website Design" is momentous variable for the success of online branding as it comes at the bottom of the ISM ranking hierarchy.

'Viral Marketing' is detected as the top level variable in the model. It means this variable depends on some other variables for inducing the success of online branding.

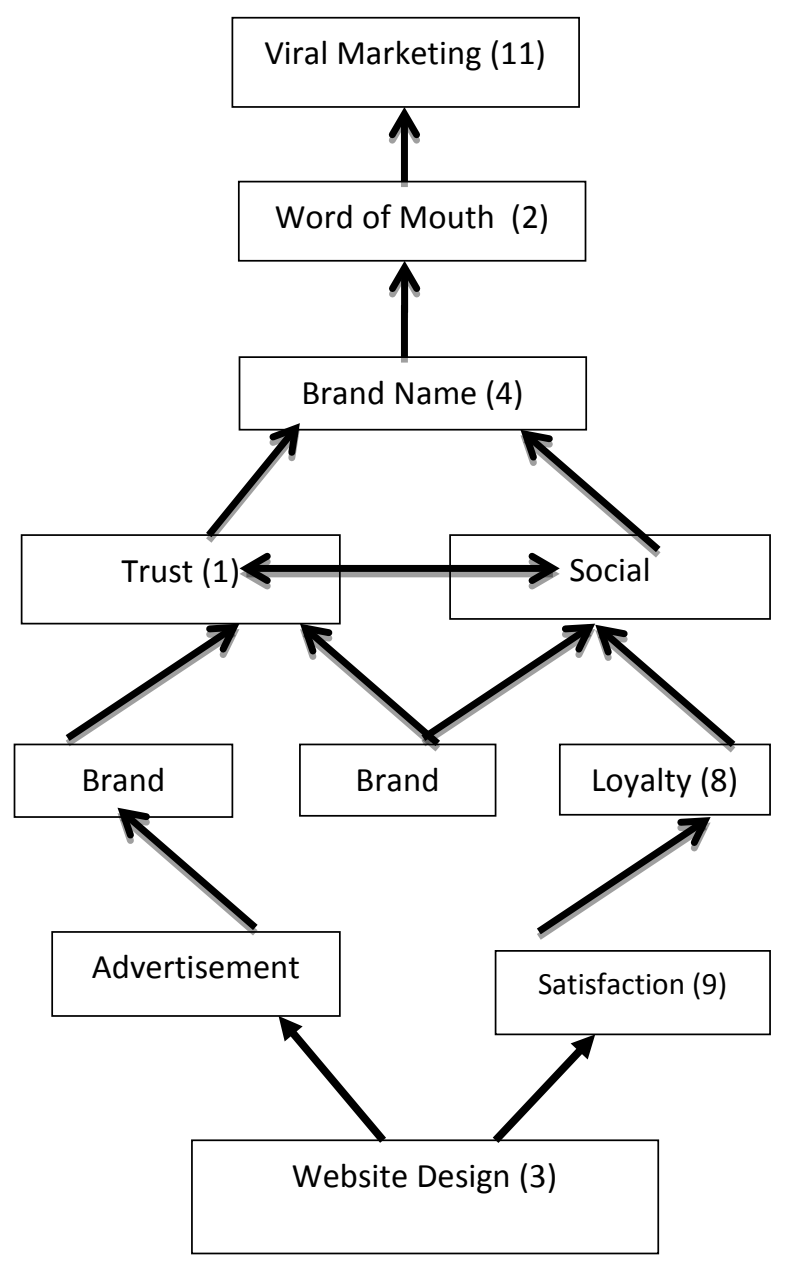

Fig. 1 ISM Hierarchy

\section{MICMAC ANALYSIS}

The motive behind MICMAC analysis is to govern the variables according to their driving and dependence power. In Table 13 the driving power and dependence power of each variable is found. 
TABLE XIII DRIVING POWER AND DEPENDENCE IN REACHABILITY MATRIX

\begin{tabular}{|c|c|c|c|c|c|c|c|c|c|c|c|c|c|}
\hline Elements & 11 & 2 & 4 & 1 & 10 & 5 & 6 & 8 & 7 & 9 & 3 & Driving Power & Ranks \\
\hline 11 & 1 & 0 & 0 & 0 & 0 & 0 & 0 & 0 & 0 & 0 & 0 & 1 & VII \\
\hline 2 & 1 & 1 & 0 & 0 & 0 & 0 & 0 & 0 & 0 & 0 & 0 & 2 & VI \\
\hline 4 & 1 & 1 & 1 & 0 & 0 & 0 & 0 & 0 & 0 & 0 & 0 & 3 & V \\
\hline 1 & 1 & 1 & 1 & 1 & 1 & 0 & 0 & 0 & 0 & 0 & 0 & 5 & IV \\
\hline 10 & 1 & 1 & 1 & 1 & 1 & 0 & 0 & 0 & 0 & 0 & 0 & 5 & IV \\
\hline 5 & 1 & 1 & 1 & 1 & 1 & 1 & 0 & 0 & 0 & 0 & 0 & 6 & III \\
\hline 6 & 1 & 1 & 1 & 1 & 1 & 0 & 1 & 0 & 0 & 0 & 0 & 6 & III \\
\hline 8 & 1 & 1 & 1 & 1 & 1 & 0 & 0 & 1 & 0 & 0 & 0 & 6 & III \\
\hline 7 & 1 & 1 & 1 & 1 & 1 & 1 & 0 & 0 & 1 & 0 & 0 & 7 & II \\
\hline 9 & 1 & 1 & 1 & 1 & 1 & 0 & 0 & 1 & 0 & 1 & 0 & 7 & II \\
\hline 3 & 1 & 1 & 1 & 1 & 1 & 1 & 0 & 1 & 1 & 1 & 1 & 10 & I \\
\hline Dependence & 11 & 10 & 9 & 8 & 8 & 3 & 1 & 3 & 2 & 2 & 1 & & \\
\hline Ranks & I & II & III & IV & IV & V & VII & V & VI & VI & VII & & 5 \\
\hline
\end{tabular}

Cluster- IV: Independent (Driver) Variable Cluster-III: Linkage Variable

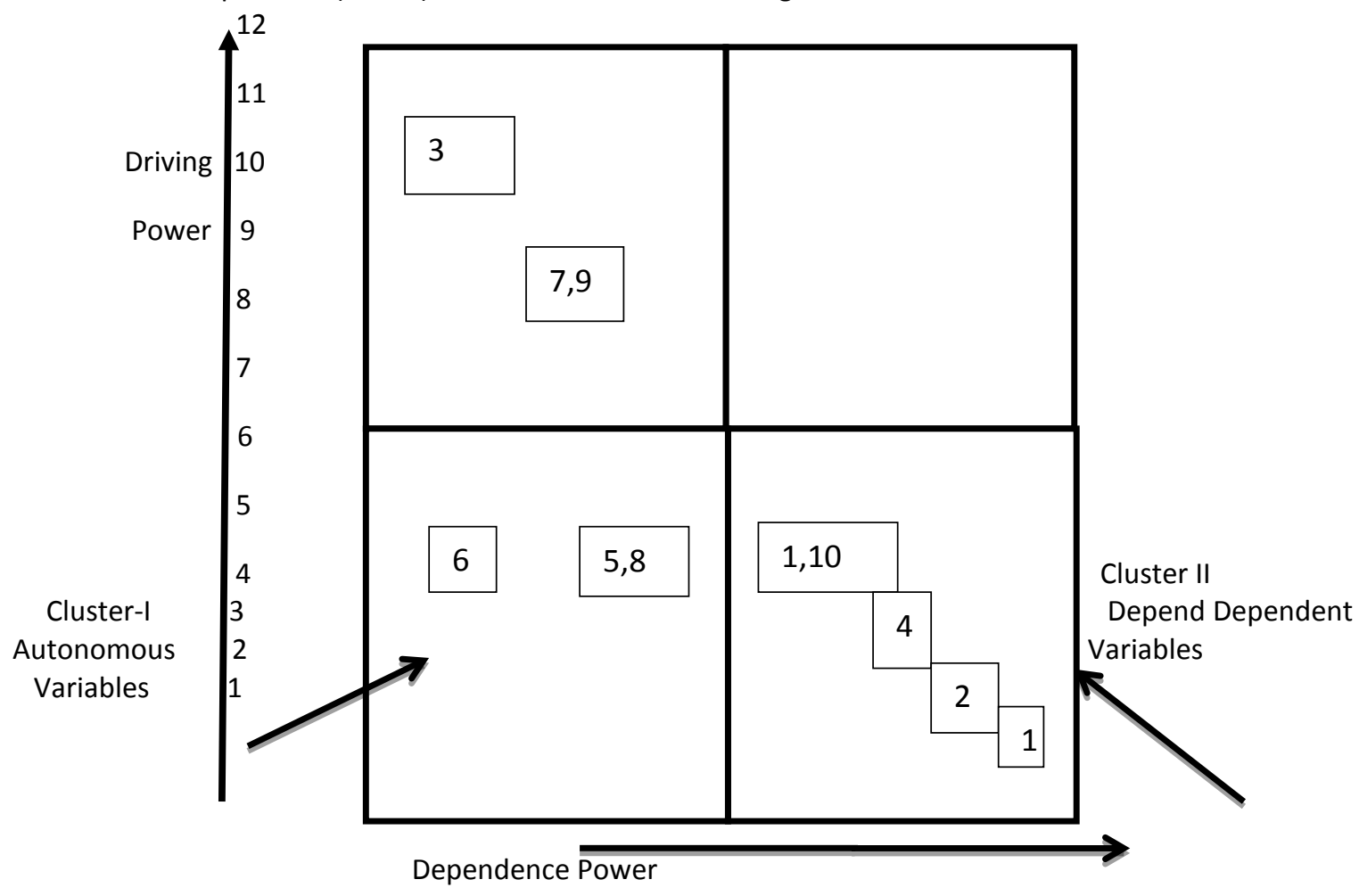

Fig.2 Driving Power and Dependence Power of each variable

According to the driving power and dependence power of these variables, these variables are divided into four clusters: Autonomous, dependent, linkage and independent variables. First cluster comprises autonomous variables weak dependence and weak driving power. Three such variable is found in this cluster in this study that is Brand Name, Brand Equity, and Loyalty which means this variable is relatively disconnected from the system. Second cluster covers variables that have strong dependence power but weak driving power. Word of Mouth, Emotional Connection, Trust, Social communities, Viral marketing is labelled as dependent variables. Third cluster belongs to the linkage variables that have strong dependence and strong driving power. In this cluster no variable has been identified. Fourth cluster comprises independent variables that have strong driving power but weak dependence. Website Design, Advertisements, Satisfaction has been 
recognised as independent or driver variables that are inducing the success of online branding.

\section{RESULT OF THE STUDY}

In this study it is found that success of online branding depends on trust, viral marketing, emotional connection, social communities. The top level variables which have weak driving power, have strong dependence on other variables. The middle level variables Brand name, Brand Equity, Loyalty are disconnected from the system and has weak dependence and weak driving power. Refinement in middle level variable can aids to attain top level variables. Refined level of top level variables helps to further increase the success of online branding. Therefore, before making an investment in the online branding the company should look into these variables that are affecting the success of online branding. Furthermore no variable is found as linkage variables that has strong dependence and strong driving power. Bottom level variables - Website Design, Advertisement and Satisfaction is found as variables having strong driving power. These variables have the capability to drive the success of online branding and can be referred to as independent variables or drivers. So companies should focus on the key variable that is 'Website Design' that will help to achieve growth of online branding in the near future.

\section{DISCUSSION}

In the present study only eleven variables is selected for modelling the factors inducing success of online branding. Apart from these variables some other variables affecting the success of online branding can be identified to develop ISM. Moreover the framework developed in the present study depends upon the opinion of few people associated with brand management and e-commerce and may contain some element of bias. With the help of ISM, a model is developed to identify the dependent, independent, linkage and autonomous variables. The model developed in the present study is not statistically validated. LISREL can be used to examine the relationship observed in the developed model. Structural Equation Modelling can also test the validity of hypothetical model. Therefore it can be applied to test the validity of the model developed in this study in future research.

\section{CONCLUSION}

In India e-commerce is growing at a good pace and more and more players are in this burgeoning sector. However there is a need to formulate strategies like online branding which can further enhance its growth. These strategies depends on a number of variables such as Trust, website design, satisfaction, advertisement, viral marketing, brand name, brand equity, Word of mouth, loyalty, social communities. This study has made an attempt to analyse the factors that are inducing the growth of online branding. For this purpose, it is important for companies to understand the characteristics and interrelationships amongst the variables that are inducing success of online branding. The ISM model developed portrays the interrelation ship among the variables. Moreover, it is determined from the model that 'Website Design' is one of the significant factors that is inducing success of online branding. The ISM model developed through this study would help the companies to decide on the variables on which they should focus to take benefit out of this online branding. Attention given by companies to these variables, according to their dependence and driving power would contribute to the growth of companies investing on online branding and also contributes to the growth of the e-commerce.

\section{REFERENCES}

[1] D.A.Aaker, “The value of brand equity," Journal of business strategy, Vol.13, No.4, pp.27-32, 1992.

[2] K.L.Ailawadi, D.R.Lehmann and S.A. Neslin, "Revenue premium as an outcome measure of brand equity," Journal of Marketing, Vol.67, No.4, pp.1-17, 2003.

[3] American Marketing Association, "Marketing definitions: A glossary of marketing terms," 1960.

[4] G. Broussard, "How advertising frequency can work to build online advertising effectiveness," International Journal of Market Research, Vol.42, No.4, pp.439-458, 2000.

[5] G.A. Churchill Jr and C. Surprenant, "An investigation into the determinants of customer satisfaction," Journal of marketing research, pp.491-504, 1982.

[6] R.C. Clauser,“ Offline rules, online tools,” The Journal of Brand Management, Vol.8, No.4, pp.270-287,2001.

[7] L.De.Chernatony, “Creating powerful brands,” Routledge, 2010.

[8] P.Doyle, Marketing Management and Strategy, 2nd ed., Prentice Hall, Harlow, 1990.

[9] W.Duan, B.Gu, and A.B.Whinston, "Do online reviews matter?An empirical investigation of panel data," Decision support systems, Vol.45,No.4, pp.1007-1016,2008.

[10] X.Drèze, and F.X.Hussherr, "Internet advertising: Is anybody watching?,” Journal of interactive marketing, Vol.17,No.4, pp.823.2003.

[11] H.Dubberly, “A model of brand,” Gain: AIGA Journal of Design for the Network Economy, Vol.1, No.1, 2000.

[12] H. Edwards and D. Day, "Creating passion brands: How to build emotional brand connection with customers," Kogan Page Publishers.2007.

[13] R.Eid, R.Y. Al Sharief and L.Hussein, "Factors Affecting the Success of Online Branding: An Empirical Study," Transdisciplinary Marketing Concepts and Emergent Methods for Virtual Environments, p.250,2012.

[14] T. Erdem and J. Swait, "Brand equity as a signaling phenomenon, ”Journal of consumer Psychology,No.7,No.2, pp.131-157,1998.

[15] D.Gehrke and E.Turban, "Determinants of successful website design: relative importance and recommendations for effectiveness," In Systems Sciences, 1999. HICSS-32. Proceedings of the 32nd Annual Hawaii International Conference on (pp. 8-pp), 1999, January, IEEE.

[16] M.Gommans, K.S. Krishnan and K.B. Scheffold, "From brand loyalty to e-loyalty: A conceptual framework," Journal of Economic and Social research,Vol.3, No.1, pp.43-58,2001.

[17] J. Hagel and A. Armstrong, "Net gain: Expanding markets through virtual communities,” Harvard Business Press.1997.

[18] D.L.Hoffman, T.P.Novak and M.Peralta, "Building consumer trust online," Communications of the ACM, Vol.42, No.4, pp.80-85, 1999.

[19] L.Jean Harrison-Walker, "E-complaining: A content analysis of an Internet complaint forum," Journal of Services Marketing, No.15,No.5, pp.397-412.2001.

[20] S. Jurvetson, What exactly is viral marketing? Red Herring, Vol.78, pp.110-112, 2000. 
[21] R.J.Kent and C.T.Allen, "Competitive interference effects in consumer memory for advertising: the role of brand familiarity,” The Journal of Marketing, pp.97-105, 1994.

[22] A.Kierzkowski, S.Mcquade, R.Waitman and M.Zeisser, "Current research: marketing to the digital consumer," The mckinsey quarterly, No.2, pp.180-183, 1996.

[23] P.Kotler and W.Pfoertsch, "Ingredient branding: making the invisible visible," Springer Science \& Business Media, 2010.

[24] M.K.Lee and E.Turban, "A trust model for consumer internet shopping," International Journal of electronic commerce, Vol.6, No.1, pp.75-91.2001.

[25] J.Leskovec, L.A.Adamic and B.A.Huberman, "The dynamics of viral marketing," ACM Transactions on the Web (TWEB), Vol. 1, No.1, p.5, 2007.

[26] L.Leuthesser, "Defining, Measuring, and Managing Brand Equity: A Conference Summary by," Marketing Science Institute, 1988.

[27] Levine, M., (2003) A branded world: Adventures in public relations and the creation of superbrands. John Wiley \& Sons.

[28] T. Mazzarol, J.C.Sweeney and G.N.Soutar, "Conceptualizing wordof-mouth activity, triggers and conditions: an exploratory study," European Journal of Marketing, Vol.41,No.11/12, pp.14751494, 2007.

[29] A.M.Muniz Jr and T.C. O'guinn, "Brand community,” Journal of consumer research, Vol.27,No.4, pp.412-432,2001.

[30] R.L.Oliver, "A cognitive model of the antecedents and consequences of satisfaction decisions," Journal of marketing research, pp.460-469.1980.
[31] R.L.Oliver, R.T.Rust and S.Varki, "Customer delight: foundations, findings, and managerial insight," Journal of retailing, Vol.73, No.3, pp.311-336.1997.

[32] F.F Reichheld and P. Schefter, "E-loyalty" Harvard business review, Vol.78, No.4, pp.105-113, 2000.

[33] J.B.Rotter, "Generalized expectancies for interpersonal trust," American psychologist, Vol.26, No.5, p.443, 1971.

[34] H.Rubinstein and C. Griffiths, "Branding matters more on the internet,” The Journal of Brand Management, Vol.8, No.6, pp.394404, 2001.

[35] D.E.Schultz and S.E.Bailey, "Customer/brand loyalty in an interactive marketplace," Journal of Advertising Research, Vol.40, No.3, pp.41-52, 2000.

[36] G.J.Simmons, "i-Branding": developing the internet as a branding tool," Marketing Intelligence \& Planning, Vol.25, No.6, pp.544562, 2007.

[37] C.Wang, P.Zhang, R. Choi and M. D'Eredita, "Understanding consumers' attitude toward advertising," AMCIS 2002 Proceedings, p.158, 2002.

[38] P.Zhang and G.M.Von Dran, "Satisfiers and dissatisfiers: A two-factor model for website design and evaluation,” Journal of the American society for information science, Vol.51, No.14, pp.12531268,2000 .

[39] A.Agarwal, R.Shankar and M.K.Tiwari, "Modeling agility of supply chain,” Industrial marketing management, Vol.36, No.4, pp.443457.2007. 